\title{
Implementation of State Economic Policy under Corporatocracy: Financial and Credit Aspect
}

\author{
Mykola Kovalenko \\ Kharkiv Regional Institute of Public Administration of the National Academy for Public \\ Administration under the President of Ukraine \\ 75 Moskovsky Avenue, Kharkiv 61001, Ukraine \\ Dmytro Ziuz \\ Kharkiv Regional Institute of Public Administration of the National Academy for Public \\ Administration under the President of Ukraine \\ 75 Moskovsky Avenue, Kharkiv 61001, Ukraine \\ Olena Smihunova \\ Kharkiv Petro Vasylenko National Technical University of Agriculture \\ 44 Alchevskikh str., Kharkiv 61002, Ukraine \\ Natalia Bondar \\ Kharkiv Petro Vasylenko National Technical University of Agriculture \\ 44 Alchevskikh str., Kharkiv 61002, Ukraine \\ Halina Omelchenko \\ Kharkiv Petro Vasylenko National Technical University of Agriculture \\ 44 Alchevskikh str., Kharkiv 61002, Ukraine \\ cross $^{\text {ref }}$ http://dx.doi.org/10.5755/j01.ppaa.19.3.26842
}

\begin{abstract}
The article brings focus to the subject of ensuring the financial capacity of Ukraine as an essential prerequisite for further transformations of the national economy. The modern problems of making state economic policy in the conditions of the corporatocracy are covered. The disadvantages of implementing the state economic policy under the influence of corporatocracy, as a new type of government, which expresses the interests of transnational corporations, are considered. Indicators are determined to assess the spread of corporatocracy in Ukraine when assessing the system of indicators of economic relations between residents and non-residents in the study of the interdependence of the monetary base and international reserves. The implications of currency board for the financial capacity of the state are analyzed. Proposals for improvement of the domestic financial and credit system have been elaborated. The study used the following methodological tools: historical, logical, analysis, tabular, graphical, and comparative methods; abstraction and concretization; generalization.
\end{abstract}

Keywords: state economic policy, transformation, economic theory, corporatocracy, currency board, financial capacity of state, financial and credit system.

Raktažodžiai: valstybès ekonominè politika, transformacija, ekonomikos teorija, korporatokratija, valiutu valdyba, valstybès finansiniai pajègumai, finansine ir kredito sistema. 


\section{Introduction}

The financial capacity of a state is determined by its ability to fulfil its internal and external financial obligations, aiming to satisfy with a sufficient amount of non-inflationary cash the needs of all the components of a comprehensive, long-term socio-economic development of society, namely: national economy, science, education, education, healthcare, culture, and more. Unlike the economies of the countries issuing reserve currencies, the main problems of the Ukrainian economy are caused by a chronic under-monetization of the economy which has been functioning in a self-liquidation mode for a long stretch of time.

Countries that have actively defended or even reserved the right to regulate their financial relations with the outside world and the movement of capital so as not to violate the national security principle and provide strategic benefits for the society as a whole are implementing measures to build a sovereign financial and credit system, alternative to today's usurious, colonial-exploitative one.

Depending on the specificity of the financial and credit system structure, the entire production potential of society, its raw-material and labour resources in their cost form get under full, unlimited control of the owner of the financial and credit system - either its own state which cares about the long-term interests of social development, or a usurious mafia that seeks to control both the national and world banking systems. All the economic potential of the country is owned by the financial and credit system owner, while all others can only use parts of it - either as "private" owners or as hired personnel, although the society may not fully realize it.

Many scholars have dealt with this problem range, in particular: J. K. Galbraith in characterizing the current global trends of replacement of state power with corporate power (Galbraith, 2009, 74); D. Perkins (Perkins, 2008) and N. Chomsky (Chomsky, 2015) in revealing the criminal activities of transnational corporations that have engaged in illegitimate military and economic interventions in many countries; K. Castoriadis in justifying the loss by the modern state of the function of maintaining 'dynamic equilibrium' (Castoriadis, 1996); J. Keynes in developing administrative ways to boost domestic demand (Keynes, 2020); and others.

The analysis of the works of the aforementioned authors and their elaborations allow us to systematize the approach to restoring the financial capacity of the state through the transformation of the established corporatocracy (monetary rule, in particular in implementing monetary policy) and return to a sovereign government, which implies strengthening of forex control, a significant increase in the level of monetization, expansion of the credit potential of the banking system to ensure the priority development of domestic production, in the first place, of innovative products with high added value.

Thus, the objectives of the article are to study the modern approaches to the transformation of the state economic policy, to determine the indicators of forming corporatocracy and the implications of currency board for the financial capacity of the state, as well as to develop proposals for improvement of the domestic financial and credit system.

To achieve this objective, the following methods are used: historical and logical - in studying the modern approaches to the transformation of the state economic policy; analytical, tabular, graphical, comparative methods - for determining the indicators of corporatocracy formation and the consequences of currency board for the financial capacity of the state; abstracting and concretizing for developing proposals to improve the domestic financial and credit system; generalization - when forming conclusions.

\section{Problems of forming the economic policy of the state in the conditions of corporatocracy}

Tony Lawson, a well-known scientist from Cambridge University, believes that economic theory is in a grave crisis explaining the events that are taking place in the real world, as well as when conducting analysis, suitable for monetary policy (Lawson, 2006, 98). Characterizing economic theory as a science, Lawson conveyed an idea that it focuses (1) on individual rather than collective action; (2) on an exchange, not on production or distribution; (3) on optimization rather than routine 
decision-making procedures; (4) on ideal competition, not on oligopoly or monopoly; (5) on structures that contribute to the emergence of constant (or declining) rather than increasing returns to scale; (6) on proposals for perfect information and accurate forecasts or 'rational expectations' and not on situations of uncertainty; (7) on final states, fixed points and equilibrium, and not on processes that take place in time; as well as on functions (utility, cost, advantages, profit, etc.) with predictable behaviour (differentiating, defining the convexity and concavity of the function graph, etc.) (Lawson, 2006, 77).

Traditionally, one of the main objects of scientific research in the field of economic theory has been the monetary policy of the state. And it is the examples of recommendations (consultations) of many modern academic economists on the models of the transformation of the state economic policy that particularly reflect the severe crisis of the current economic theory. For a better understanding of these processes, we will group the models, widely used in the current practice, by different types.

The first type denies the possibility of consulting based on political and economic models. Normative models can be formulated, but the researcher must be fully aware that there is no way to really implement them because the behaviour of politicians is entirely determined by their own interests, political process, and external dependencies. In this case, the main task of scientists is a complimentary analysis of political and economic phenomena.

The second type involves consulting based on a "limited" model, in which a certain level of political decision-making acts as an exogenous factor. The limitation is set not in accordance with theoretical or empirical conclusions but based on a specific situation. For example, an economist may advise the president on reducing corruption in the country, assuming that the president is really interested in it (and thereby deliberately excluding from his analysis the fact that the president himself may be endogenized in the model and maybe an essential recipient of corruption rents). This view of consulting concerning political and economic models is called the 'normative turn' in the theory of social choice. It is dominant among those who are engaged in political and economic research (Brains, 2006). It is also important to consider one of the most significant conclusions of the Austrian economic school: the real problems of implementing specific economic ideas are not the conceptual development of optimal mechanisms, but the technical aspects of their implementation. Therefore, to exclude some aspects deliberately from the analysis can render it impossible to fully implement the model, or worse, to implement it with severe distortions that only aggravate the situation. In practice, this can be observed quite often.

The third type shifts the focus of consulting from politicians to broader social groups. In this case, the society and its citizens become the primary recipient of the economist's advice, and the tasks of consulting are directly intertwined with those of education (Pitlir, 2001). The interest in this type is due to the growing volume of empirical evidence in favour of the fact that the modern economic theory influences the real world not so much through the rational assimilation of its recommendations, but by forming values, culture and individual public perceptions. For some countries, such models as 'strategic trade policy' (the sphere of the international economy), 'nuclear and military deterrence' (the sphere of trade relations and formal political science), 'democratic world' or 'democratic or liberal values' (the sphere of struggle with global and regional competitors), 'independence of central bank' or 'financial literacy' (the field of justification of usury, speculative activity, debt dependency) are vivid examples of theoretical concepts that have become a real factor of development of specific political, economic and social processes.

The fourth type is characterized by specialization in consulting of public authorities. In this case, the consultants themselves have to assume that the reaction of politicians and public officials will be distorted by their interests and incentives. Therefore, it is necessary to constantly adjust the content of their consultations in order to achieve the previously set goals. For example, it may be advisable for a consultant to act as an 'alarmist', deliberately overestimating the scale of the threat in order to force a particular political institute to make the 'right' decision. 
Unfortunately, in the current conditions, the formation of groups of scientists according to one or another type, defined by us, is to a large extent connected with the commercial perception of this "scientific" activity. Moreover, nowadays there is outstanding literature on "political economy of consulting" which determines the behaviour of consultants as a banal seeking of rent. Or when there is deliberate falsification of scientific results, which can be a tool for obtaining additional research funding. Or when some authorities limit severely the "scoring" space for scientists' publishing their research findings, sending them to commercial international scientometric databases which, in turn, are not without their editorial preferences. Not to mention that in reality, an economist is obviously not entirely impartial, in many cases being guided by their own world outlook and ideological views (Bazilevich, 2015, 431).

Thus, we can observe certain patterns of emerging contradictions within a real economy, the interests of which are focused on facts, well-known from economic experience and impartial economic science whose function is to identify the interconnection of ideas, models, concepts and to find solutions to many existing economic and social problems. Professor Viktor Volkonskyi, one of the reviewers of the book "National Economy Model" by a famous contemporary economist Haydar Bash, in this regard stated that in economic science, there is an unquestioned monopoly of the liberalmonetarist direction, which supersedes all other directions contradicting it in theory, in making of the state monetary policy of the countries within the control of the western community, and in the majority of university courses and textbooks, from which the young people of these countries study. All theories and research works, problems and facts that contradict this dominant direction, are forced in various ways out of the perspective of scientists, politicians, students in an attempt to present them as an accessory, minor exceptions or additions to the fundamental laws of economics. As a result, this "main body of knowledge", the mainstream of economic science, becomes a reflection of the evernarrowing range of problems and facts of the socio-economic life of humankind, ignoring the real issues that have long been the most pressing challenges and threats to the lives of most of the inhabitants of this planet (Haydar Bash, 2020, 9).

The current crisis of economic theory in general and the monetary policy of the state, in particular, can be resolved primarily by reorienting it to the predominance of normative elements. This must be done with an understanding of the need for a radical change, at the global and national levels, of the current economic system which is oriented to exploitation and consumption rather than to creation. Consequently, there will be diversity and construction of the modern economic segments, which will provide new methodological requirements to the advancement of various domains of scientific knowledge aimed at the parity and comprehensive development of each of the existing human civilizations.

J. K. Galbraith, characterizing the current global trends of replacing state power with the power of corporations, noted that a corporation-governed society infers economic disasters and crimes. It becomes incapable of yielding benefits and eventually ceases to exist (Galbraith, 2009, 74). The society has allowed taking away from the states their function of maintaining a 'dynamic equilibrium'. According to K. Castoriadis, this is supporting equality between the rhythms of consumption growth and productivity gains based on the sovereign right of the state to impose bans on imports or exports occasionally, set customs barriers (Castoriadis, 1996) or, in the spirit of Keynes's ideas, stimulate domestic demand in an administrative way (Keynes, 2020).

Any control over this 'dynamic equilibrium' is beyond the capabilities or desires of the vast majority of states today. The only economic task that the country is allowed and ordered to perform is to implement the imposed "budget" by controlling and restraining demands for more decisive government intervention in the business sector, or protection of the population from the grave consequences of market anarchy. At the same time, from the point of view of the state, the distinction between the domestic and world market is lost; in general, there appears to be no difference between the concepts of 'internal' and 'external'. As Z. Bauman, Professor of the University of Leeds, metaphorically remarks, in the "globalization cabaret", the state is engaged in striptease, and at the end of the performance all it has on is the necessary minimum - its repressive power. When its 
material basis is destroyed, its sovereignty and independence are abolished, the political class is eliminated, and the nation-state turns into a mere security service for transnational corporations. As a result of this "striptease", the role of the state is reduced to the functions of a local police station (Bauman, 2004, 38-39).

D. Perkins (Perkins, 2008) and N. Chomsky (Chomsky, 2015) provide comprehensive data on the criminal activities of transnational corporations which, using the US political and military potential to their own advantage, organize coups d'état, appoint dictators in Latin America, and commit utterly illegitimate military and economic interventions in many countries of the world. As a result, these countries face the waging of wars, socio-economic decline and disorder, and aggravated problems of poverty.

Thus, in recent decades, the world has seen the emergence of a new form of governance - the corporatocracy, due to which the real power belongs to the beneficiaries of powerful transnational corporations, forming conglomerates of corporations, banks, the media, supranational regulators, controlled governments, parliaments, special services, etc. The goal of this power is severe exploitation of countries' national resources (labour, natural, etc.) for the corporations' benefit, the constant expansion of territories and spheres of influence, and maximization of various forms of profit-making.

\section{Indicators of corporatocracy formation and implications of currency board for the financial capacity of the state}

The economic indicators of setting the rule of corporatocracy in a particular country can be the external sector statistics which reflects the economic relations between residents and nonresidents and consists of the following components: balance of payments, international investment position, external debt, foreign exchange rates systematically. The legal framework for the compilation and dissemination of the statistics on the external sector of the Ukrainian economy comprises the Law of Ukraine "On the National Bank of Ukraine", IMF Special Data Dissemination Standard, and the articles of the IMF Agreement.

Let's analyze the key positions of this statistical data for the period from 2004 to 2019 (see Table 1). Despite the presence of an overall positive balance for the reviewed period, the ways to achieve this have changed dramatically. Thus, beginning in 2006, Ukraine compensates the negative value of the Current account (consists of the Balance of trade in goods and services, the Balance of primary income and the Balance of secondary income) by increasing capital borrowing for the financial account, which directly correlates with the growth of the gross external debt, in particular with the growth of the external state and state-guaranteed debts.

Table 1. Dynamics of the changing nature of economic relations between the residents and non-residents of Ukraine from 2004 to 2019* (Balance of payments and other statistics, 2020; Balance of payments of Ukraine, 2020)

\begin{tabular}{|l|c|c|c|c|c|}
\hline \multirow{2}{*}{ INDICATORS } & \multicolumn{5}{c|}{ YEARS } \\
\cline { 2 - 6 } & 2004 & 2013 & 2017 & 2018 & 2019 \\
\hline $\begin{array}{l}\text { Components of Balance of payments, mIn } \\
\text { USD: }\end{array}$ & & & & & \\
\hline A. Current account & $\mathbf{6 9 1 1}$ & $\mathbf{- 1 6 5 1 8}$ & $\mathbf{- 2 4 4 2}$ & $\mathbf{- 4 3 6 7}$ & $\mathbf{- 1 3 2 2}$ \\
\hline Balance of goods and services & 4980 & -15634 & -8644 & -11367 & -12383 \\
\hline Export of goods and services & 39461 & 81719 & 53868 & 59135 & 63421 \\
\hline Import of goods and services & 34481 & 97353 & 62512 & 70502 & 75804 \\
\hline Balance of goods & 2742 & -22128 & -9663 & -12714 & -14332 \\
\hline Export of goods & 30581 & 59106 & 39701 & 43341 & 46113 \\
\hline Import of goods & 27839 & 81234 & 49364 & 56055 & 60445 \\
\hline Balance of services & 2238 & 6494 & 1019 & 1347 & 1949 \\
\hline Export of services & 8880 & 22613 & 14167 & 15794 & 17308 \\
\hline
\end{tabular}




\begin{tabular}{|l|c|c|c|c|c|}
\hline \multirow{2}{*}{ INDICATORS } & \multicolumn{5}{|c|}{ YEARS } \\
\cline { 2 - 5 } & 2004 & 2013 & 2017 & 2018 & 2019 \\
\hline Import of services & 6642 & 16119 & 13148 & 14447 & 15359 \\
\hline $\begin{array}{l}\text { Remuneration of labour of persons working } \\
\text { abroad (balance) }\end{array}$ & 212 & 6757 & 9110 & 11478 & 12877 \\
\hline $\begin{array}{l}\text { Investment income, including foreign-exchange } \\
\text { outflow (balance) }\end{array}$ & -857 & -9790 & -6531 & -8130 & -8124 \\
\hline B. Capital account & $\mathbf{2 1}$ & $\mathbf{- 6 0}$ & $-\mathbf{4}$ & $\mathbf{3 7}$ & $\mathbf{3 8}$ \\
\hline $\begin{array}{l}\text { C. Capital borrowing for financial account } \\
\text { (transactions of the private and public } \\
\text { sectors) }\end{array}$ & $\mathbf{4 3 9 3}$ & $\mathbf{- 1 8 6 0 1}$ & $\mathbf{- 5 0 1 2}$ & $\mathbf{- 7 2 0 7}$ & $\mathbf{- 7 2 6 4}$ \\
\hline Direct investment (balance) & -1711 & -4079 & -2593 & -2360 & -2422 \\
\hline Portfolio investment (balance) & -2067 & -8787 & -1800 & -2080 & -5134 \\
\hline Other investment (balance) & 8299 & -6375 & -137 & -1061 & 1538 \\
\hline Joint stock & -61 & 1180 & 110 & -9 & 49 \\
\hline Debt securities & 2134 & 7602 & 1693 & 2122 & 5496 \\
\hline Balance (A+B-C) & $\mathbf{2 5 3 9}$ & $\mathbf{2 0 2 3}$ & $\mathbf{2 5 6 6}$ & $\mathbf{2 8 7 7}$ & $\mathbf{5 9 8 0}$ \\
\hline Gross external debt, mIn USD & $\mathbf{3 0 6 4 7}$ & $\mathbf{1 4 2 0 7 9}$ & $\mathbf{1 1 5 4 5 1}$ & $\mathbf{1 1 4 7 1 0}$ & $\mathbf{1 2 1 7 3 9}$ \\
\hline $\begin{array}{l}\text { External debt of the general public } \\
\text { administration sector, mln USD }\end{array}$ & $\mathbf{1 0 0 5 8}$ & $\mathbf{2 9 9 2 2}$ & $\mathbf{3 8 ~ 8 8 6}$ & $\mathbf{4 0} 128$ & $\mathbf{4 4 5 3 1}$ \\
\hline $\begin{array}{l}\text { External debt of the National Bank of } \\
\text { Ukraine, mln USD }\end{array}$ & $\mathbf{1 6 9 5}$ & $\mathbf{1 7 7 5}$ & $\mathbf{7 4 3 8}$ & $\mathbf{7 9 3 8}$ & $\mathbf{7 3 0 3}$ \\
\hline USD-to-UAH exchange rate (as of 31.12) & $\mathbf{5 . 3 1}$ & $\mathbf{7 . 9 9}$ & $\mathbf{2 8 . 0 7}$ & $\mathbf{2 7 . 6 9}$ & $\mathbf{2 3 . 6 9}$ \\
\hline
\end{tabular}

* From 2014 the data does not take into account the statistics on the Autonomous Republic of Crimea

The exploitation of Ukraine's labour resources for the benefit of other economies is evidenced by a significant increase in remuneration of the Ukrainians who became Ostarbeiter. For instance, only official incoming receivables from the remuneration of their overseas employment increased more than 60-fold between 2004 and 2019. Along with that, the external debt of Ukraine increased from $\$ 30.6$ billion to $\$ 121.7$ billion, including the increase in the public sector debt from $\$ 10.1$ billion to $\$ 44.5$ billion.

At the same time, the outflow of foreign currency from 2004 to 2019 increased almost tenfold. This is a kind of payment to non-residents for investments that were previously made in the economy of our country, as well as repayment of interest on previously taken credits and loans. It should be noted that in 2019 the Government of Ukraine repaid \$5.017 billion of debt, the Central Bank - \$843 million, including $\$ 1.945$ billion paid to the IMF. In 2019, this amount was almost $\$ 5.9$ billion, that is, about UAH139 billion, which is more than one and a half times higher than that year's total expenditures on healthcare (UAH 38.562 billion) and education (UAH 51658 billion).

The issues of accumulation, freezing of the country's foreign currency funds in international reserves, and much more their replenishment through increasing external, expensive debts, are quite controversial. The declarative nature and groundlessness of such an indicator as to the ratio of the country's imports to its international reserves, often used in various reports of the National Bank of Ukraine, do not withstand the slightest criticism. In the current conditions of the extremely low level of investment support for the development of domestic industry, implementation of innovative projects, etc., the National Bank and the Government of Ukraine are more concerned about the support of foreign producers and transnational financial institutions.

From the end of 2004, except for 2012-2013, the issue of Ukrainian hryvnia is based on the use of currency board (see Fig. 2). The hryvnia became a derivative of foreign borrowings which are primarily expressed in US dollars (securities, currency, deposits). 


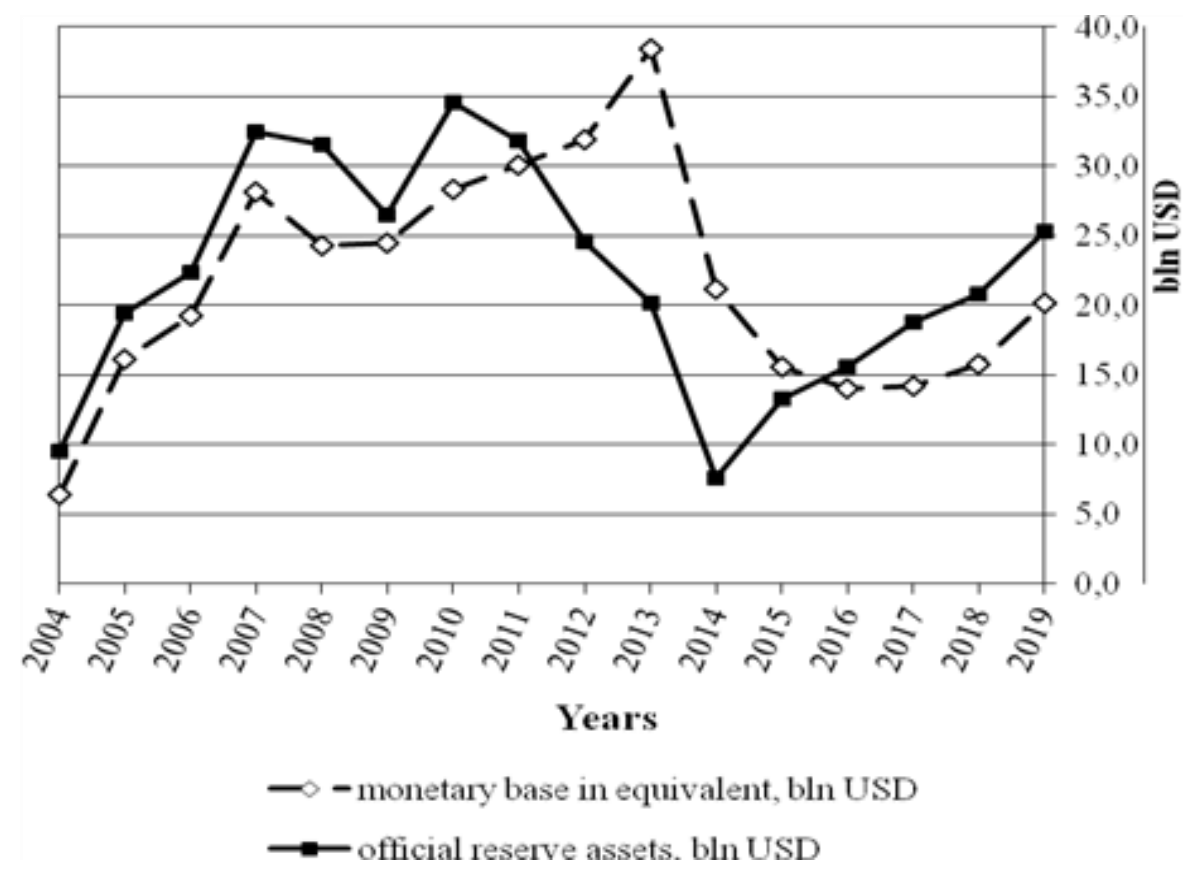

Fig. 1. The interdependence of the monetary base and international reserves of the National Bank of Ukraine in the period of 2004-2019

Source: National Bank of Ukraine, 2020; Balance of payments, 2020

Since the second half of 2011, there has been a decline in international reserves with a simultaneous increase in the monetary base at the expense of internal sources (government bonds and refinancing). The economic base is an aggregate of certain types of cash and transferable deposits of the National Bank of Ukraine, which ensure the growth of monetary aggregates and lending to the economy. The value of the economic base was maximal at the end of 2013 when its equivalent amounted to $\$ 38.4$ billion, which certainly boosted business activity, contributed to the reduction of unemployment to $7.7 \%$ (the lowest level for the period of 2009-2019), a decrease in the NBU refinancing rate to $6.5 \%$, an increase in domestic credit (by $15 \%$ ), stabilization of prices (almost zero inflation), a real wage index increase (by $28.8 \%$ in 2011-2013), etc.

However, as a result of the devaluation and slowing down of the hryvnia monetary base growth, in 2014 Ukraine returned again to the currency board regime and, as of the end of 2016, the economic base, expressed in dollar terms, decreased to $\$ 14$ billion. The ratio of the monetary base to international reserves, respectively, is already less than 1 (see Table 2). In the following 20172019 , the ratio of the monetary base to international reserves stabilized at $0.76,0.76$ and 0.80 .

Table 2. The ratio of monetary base to international reserves in 2004-2019.

\begin{tabular}{|c|c|c|c|c|c|c|c|c|}
\hline YEAR & $\mathbf{2 0 0 4}$ & $\mathbf{2 0 0 5}$ & $\mathbf{2 0 0 6}$ & $\mathbf{2 0 0 7}$ & $\mathbf{2 0 0 8}$ & $\mathbf{2 0 0 9}$ & $\mathbf{2 0 1 0}$ & $\mathbf{2 0 1 1}$ \\
\hline RATIO & 0.67 & 0.83 & 0.86 & 0.87 & 0.77 & 0.92 & 0.82 & 0.94 \\
\hline YEAR & $\mathbf{2 0 1 2}$ & $\mathbf{2 0 1 3}$ & $\mathbf{2 0 1 4}$ & $\mathbf{2 0 1 5}$ & $\mathbf{2 0 1 6}$ & $\mathbf{2 0 1 7}$ & $\mathbf{2 0 1 8}$ & $\mathbf{2 0 1 9}$ \\
\hline RATIO & 1.30 & 1.91 & 2.81 & 1.17 & 0.90 & 0.76 & 0.76 & 0.80 \\
\hline
\end{tabular}

Thus, the Washington Consensus was a continuation of the traditions of colonial administration in the monetary sphere. At first, there was a classic currency board of the Bank of England which controlled the economies of the colonies of the British Empire with hidden tribute; then in the late 19th - 20th centuries, the gold standard of the leading nations of the West, and the Bretton Woods dollar system after 1944. The Washington Consensus policy, which began to be used 
in the late 20th century by a number of less developed and post-socialist countries, required from their central banks, independent of their own governments but dependent on supranational regulators and corporate lobbies, to make their national money derivative of the US dollar. On this basis, the world system of finance and trade gives enormous benefits to the United States, and the owners of the US Federal Reserve virtually conquer the entire world. With the currency board regime, less developed countries turn into colonies, and their central banks become the agents of the metropolis in conducting exploitation.

A common mistake made by many countries in the recent history of humanity regarding the issue of money is its attachment to a specific asset (gold, currency, etc.) to secure the "value" of money. The amount of money is limited only by the capacity of the economy. Money is a tool that drives economic activity to produce goods and services. This is the so-called stimulating function of money, due to which money becomes an incentive to express intentions regarding production and consumption. Implementation of this function enables the state to be economically sovereign and to ensure mobilization of all its factors of production for the sake of its long-term socio-economic development. Thus, money is not just a link in the economy. On the contrary, they play a significant role in driving production and consumption. It is on this understanding of the quantity theory of money in the conditions of ensuring sufficient demand that D. M. Keynes insisted, stating that while there is underemployment of factors of production, the extent of their use will vary in the same proportion as the amount of money; if full employment is achieved, then prices will also change in the same proportion as the amount of money (Keynes, 2020).

Particular emphasis should be laid on the negative impact of the hryvnia exchange rate fluctuations on maintaining macroeconomic stability and price parity in forming foreign trade relations. During the mentioned period, the hryvnia depreciated substantially, which almost symmetrically reflected on the intensification of inflationary processes with all its negative consequences for the country's socio-economic state and, at the same time, with considerable benefits for the corporatocracy.

\section{Improvement of the domestic financial and credit system as an important factor of the sovereign economic policy of the state}

A prerequisite for forming a sovereign state economic policy aimed at the country's socioeconomic development and protection of the interests of the people is to increase the financial capacity of the state by creating the necessary demand and providing the adequate supply of money for implementation of an intense investment and innovation activity. The demand for money should be determined by the real sector of the manufacturing economy, state-owned banks and development funds, subject to a zero refinancing rate. However, the transition to targeting inflation should not be made due to neglecting other macroeconomic policy goals which, apart from achieving a stable hryvnia, also include increased investment, production output and employment. These goals can be prioritized and set in the form of restrictions. They can be achieved through the flexible use of all available government tools for monetary and foreign exchange regulation, which must be applied on a systematic and synergistic basis.

Under the current condition of the domestic economy, priority should be given to the growth of production and investment within the established limits on inflation and hryvnia exchange rate. To keep inflation within the established limits, a comprehensive system of state measures is required to deal with the issues of price setting and pricing policy-making, promoting internal market competition, rigid state monetary and banking control, protectionism, etc.

An analysis of the experience of countries that have achieved rapid socio-economic advancement shows the need for a comprehensive approach to the formation of money supply, with the sole focus on the domestic sources of currency issue and their binding to the implementation of government target programs that are aimed at solving the most important problems of social development. The priority source of currency issue is refinancing of banking institutions, provided 
that such emission is focused exclusively on lending to the real economy and investing in priority areas of development. This can only be achieved if the present financial and credit system is upgraded. Therefore, to form a financial model of a new domestic financial system, adequate to the task of ensuring the financial capacity of the state, the following set of measures is proposed (Kovalenko, 2012; Kovalenko, 2015):

- change of the NBU status and establishment of state banking control over its activity, which provides for a considered system of counterbalances;

- legislative inclusion into the NBU credit policy and practices of goals providing for the creation of conditions for economic growth, an increase of investments, production output and employment;

- regulation of money supply, predominantly by refinancing of commercial banks, secured by the loan requirements of manufacturing enterprises, government bonds, and development institutions implementing state targeted programs;

- in order to exclude the stimulation of capital export and currency speculation, the National Bank should suspend the acceptance of foreign securities and foreign assets of domestic banks as collateral for loans;

- creation and maintaining a significant resource potential of state development banks at both state and regional levels through their refinancing by the National Bank secured by investment projects approved by the government and municipal authorities in accordance with established priority development areas, state and regional target programs;

- extension of the collateral list of the NBU by including promissory notes and bonds of solvent enterprises operating in priority areas, and development institutions (state development banks, innovation and investment funds, development funds, state commercial, scientific corporations of scientific and technological development, etc.), guarantees of the Cabinet of Ministers and regional public authorities;

- in order to ensure stable lending conditions, to prohibit commercial banks from unilateral reviewing of the credit agreement terms;

- switching to the fixed exchange rate of hryvnia with the establishment of pre-announced exchange rate fluctuations which should be maintained for an extended period of time;

- state-owned commercial banks should consistently substitute foreign currency loans provided to economic entities, servicing settlements with domestic contractors, with hryvnia loans, backed up by appropriate collateral from the NBU;

- introduction of additional rules of banking supervision that will stop the flow of money, issued for refinancing production activities and investment, to the financial and foreign exchange markets;

- strengthening of state supervision over non-banking financial institutions (insurance companies, credit unions, pawnshops, leasing firms, pension funds, investment funds, financial companies, etc.), in particular over their currency operations.

During monetary policy-making, the National Bank together with the related ministries should assess through various channels the macroeconomic impact of hryvnia issue: to refinance commercial banks for liabilities of manufacturing enterprises, bonds of the government and development institutions, aiming to implement government target programs, for replacement of foreign currency loans, for purchase of foreign currency to accelerate technological modernization of manufacturing enterprises, etc.

\section{Conclusions}

1. In the current context, the state, its institutions and structures should play a particularly important role in the country's economy. This is due to both the need for an optimal balance between 
market and government regulators, as well as the requirements of balancing the public interest, maintaining social stability and strengthening security measures against endogenous and exogenous threats.

2. The functions of the state in the financial sphere are filled with real meaning depending on the economic, social, cultural, political conditions in a specific country, reflecting the impact of a number of subjective factors of public-administrative decision-making: dominant and alternative theoretical concepts concerning government involvement in economic activity, government policy priorities in a specific situation.

3. Based on the findings of the research, the use of a number of external sector statistics was substantiated; these can serve as indicators of corporatocracy in Ukraine and be an important source of information about state economic policy-making for alternative political forces.

4. The functional content of the financial and credit system must be completely different, making the NBU a chain of the national public administration system, the real power over which is to be shifted from the IMF and corporate lobbies to the Cabinet of Ministers of Ukraine, provided it is composed of real experts and politicians, and not of politically engaged amateurs and compradors. This should undoubtedly be preceded by actual separation of the oligarchic clans from governance.

5. Improvement of the national monetary system is an important means of ensuring the financial capacity of the state, an essential factor of modern public administration and foresight of long-term success. Without this, there is absolutely no sense to argue over the prospects of changing the colonial-oligarchic model of the country's economy based on usurious exploitation that is leading to the economic genocide of the people of Ukraine.

\section{References}

1. Balance of payments and other statistical information compiled on the basis of the BPM6 (the sixth edition of the IMF's Balance of Payments and International Investment Position Manual, 2009). https://bank.gov.ua/statistic/sector-external/data-sector-external [2020.03.05].

2. Balance of payments of Ukraine. https://index.minfin.com.ua/ua/economy/balance [2020.03.01].

3. Brains, S. J. 2006. "The Normative Turn in Public Choice." Public Choice 127 (3-4), 245250.

4. Cornelius Castoriadis. 1996. La crise des sociétés occidentales. La montée de l'insignifiance. Paris: Seuil, 14-15.

5. Keynes, J. The General Theory of Employment, Interest, and Money. https://www.files.ethz.ch/isn/125515/1366_KeynesTheoryofEmployme-nt.pdf [2020.03.01].

6. National Bank of Ukraine. Economic and Financial Indicators of Ukraine. https://bank.gov.ua/statistic/sdds/sdds-data [2020.02.24].

7. Pitlir, H. 2001. "Politikberatung der Offentlichkeit." Perspcktiven der Wirtschaftspolitik 2 (1), 61-73.

8. Базилевич, В., Ильин, В. 2015. Экономико-философская мысль современного мира. К.: Знання.

9. Бауман, 3. 2004. Глобализация. Последствия для человека и общества. М.: Издательство «Весь Мир».

10. Гелбрейт, Дж. К. 2009. Экономика невинного обмана: правда нашего времени. М.: Издательство «Европа».

11. Коваленко, М. М. 2012. Державне регулювання банківського сектора України: теорія, методологія, практика. Х. : ЦД.

12. Коваленко, М. М. 2015. Держава та банківський сектор: реалістична організація взаємодії : монографія. X. : Tim Publishing Group.

13. Лоусон, Т. 2006. “Современная «экономическая теория» в свете реализма.” Вопросы экономики 2, 77-98. 
14. Перкинс, Дж. 2008. Тайная история американской империи. Экономические убийцы и правда о глобальной коррупции. М. : Альпина бизнесбукс.

15. Сколько стоит обслуживание долгов Украине. http://dengi.ua/finance/306324-Skol-kostoit-obsluzhivanie-dolgov-Ukraine [2020.03.04].

16. Хайдар, Баш. Модель Национальной Экономики - новая экономическая система. http://www.vixri.ru/wp-content/uploads/2011/12/Nationaleconomicmodel.pdf [2020.03.04].

17. Хомский, Н. 2015. Создавая будущее: Оккупации, вторжения, имперское мышление и стабильность М. : Альпина нон-фикшн.

Mykola Kovalenko, Dmytro Ziuz, Olena Smihunova, Natalija Bondar, Halina Omelchenko

Valstybės ekonominès politikos ịgyvendinimas korporatokratijos sąlygomis: finansinis ir kredito aspektas

\section{Anotacija}

Straipsnyje akcentuojama Ukrainos finansinio pajègumo užtikrinimo problema, nes ji ypač svarbi ịgyvendinant vidaus ekonomikos pertvarkymus. Tyrimo metu buvo išanalizuotos šiuolaikinès valstybès ekonominès politikos formavimo problemos korporatokratijos sąlygomis. Daug dėmesio buvo skirta viešojo sektoriaus ekonomikos politikos formavimo apžvalgai valstybèje, kuriai įtaką daro korporatokratija. Yra pastebèta, kad ši nauja valdžios rūšis, besivadovaujanti tarptautinių korporacijų interesais, daro žalą politikos formavime. Autoriai nustatè rodiklius, kurie gali būti naudojami vertinant korporatokratijos lygi Ukrainoje atsižvelgiant $\mathfrak{i}$ valiutos lygi ir tarptautinių atsargų tarpusavio priklausomybę. Straipsnyje išsamiai pristatomos valiutų valdybos veikimo pasekmès valstybès finansinėms galimybėms. Autoriai pateikia pasiūlymus dèl Ukrainos vidaus finansų ir kredito sistemos patobulinimo.

Mykola Kovalenko - Dr. habil. in Public Administration, Professor of Economic Theory and Finances Department, Kharkiv Regional Institute of Public Administration of the National Academy for Public Administration under the President of Ukraine.

e-mail: kovnn1@gmail.com

Dmytro Ziuz - Postgraduate student of Economic Theory and Finances Department, Kharkiv Regional Institute of Public Administration of the National Academy for Public Administration under the President of Ukraine.

email: $\underline{31036 @ u k r . n e t}$

Olena Smihunova - Ph.D. (Economic Sciences), Associate Professor Department of Organization of Production, Business and Management, Kharkiv Petro Vasylenko National Technical University of Agriculture.

E-mail: elenasmigunova@gmail.com

Natalia Bondar - Ph.D. (Historical Sciences), Associate Professor UNESCO Chair for "Philosophy of Human Communication", Social and Humanity Sciences, Kharkiv Petro Vasylenko National Technical University of Agriculture.

E-mail: nbon79@gmail.com 
Halina Omelchenko - Senior Lecturer, UNESCO Chair for "Philosophy of Human Communication", Social and Humanity Sciences, Kharkiv Petro Vasylenko National Technical University of Agriculture.

E-mail: galinomelchenko@gmail.com

Mykola Kovalenko - viešojo administravimo daktaras, Nacionalinės viešojo administravimo akademijos prie Ukrainos Prezidento Charkovo regioninio viešojo administravimo instituto Ekonomikos teorijos ir finansų katedros profesorius.

El. paštas: kovnn1@gmail.com

Dmytro Ziuz - Nacionalinès viešojo administravimo akademijos prie Ukrainos Prezidento Charkovo regioninio viešojo administravimo instituto Ekonomikos teorijos ir finansų katedros aspirantas.

El. paštas: $\underline{31036 @ u k r . n e t}$

Olena Smihunova - Ph.D. (Ekonomikos mokslai), Charkovo P. Vasylenko Nacionalinio žemès ūkio universiteto Gamybos, verslo ir vadybos organizavimo katedros docent.

El. paštas: elenasmigunova@gmail.com

Natalija Bondar - Ph.D. (Istoriniai mokslai), Charkovo P. Vasylenko Nacionalinio žemės ūkio universiteto UNESCO socialinių ir humanitarinių mokslų „Žmonių bendravimo filosofijos“ katedros docent.

El. paštas: $\underline{\text { nbon79@gmail.com }}$

Halina Omelchenko - Charkovo P. Vasylenko nacionalinio žemès ūkio universiteto UNESCO socialinių ir humanitarinių mokslų „Žmonių bendravimo filosofijos“ katedros vyresnioji dèstytoja. El. paštas: galinomelchenko@gmail.com 